\title{
THE DAY OF ATONEMENT AS A HERMENEUTICAL KEY TO THE UNDERSTANDING OF CHRISTOLOGY IN HEBREWS
}

\author{
Hanno Langenhoven, Eliska Nortjé \\ Annette Potgieter and Yolande Steenkamp \\ University of Pretoria, Pretoria
}

\section{ABSTRACT}

This study contributes to the discussion of the hermeneutics of Hebrews by considering the book's background thought and central theme. Specifically, we attempt to show how the worldview(s) and references to the Israelite cult form the décor against which the book's Christology acts out a new, supreme story of atonement. Crucial to the Christology of Hebrews is the role of Christ as High Priest, found in Hebrews in the context of the Jewish festival, the Day of Atonement. It is precisely this relationship between the Christology of Hebrews and the Day of Atonement that forms the focus of the study. Focusing on both the background and central theme of the book (its Christology), this study proposes that the priesthood and the Day of Atonement define the contours within which the Christology of Hebrews should be interpreted. We argue that the Day of Atonement functions as a hermeneutical key to the Christology of Hebrews and - since this is the book's central theme - to the book of Hebrews as a whole. We propose, furthermore, that references to the Day of Atonement offer an interpreted religious and liturgical space for Christ to function as the superior High Priest. In this capacity, He is able to bring about a new covenant in which perfect atonement is achieved once and for all. 


\section{Introduction}

Contemporary scholarship on Hebrews approaches the hermeneutics of the book from three main focal points, namely the author's use of OT citations, the book's background thought, and the central theme and structural analysis of the book (Son 2005:3). This study aims to contribute to the discussion of the hermeneutics of Hebrews by considering the second and third of these areas. Specifically, we will attempt to show how the worldview(s) and references to the Israelite cult form the décor against which the book's main character acts out a new, supreme story of atonement. "Main character," in this image, carries a double reference. Firstly, it refers to the book's central theme, while at the same time acknowledging Christ as the main Actor in the supreme narrative of salvation told by the author. Put differently: Jesus Christ is central to Hebrews (Du Toit 2002:150). Crucial to the Christology of Hebrews, in turn, is the role of Christ as High Priest, found in Hebrews in the context of the Jewish festival, the Day of Atonement. ${ }^{1}$ It is precisely this relationship between the Christology of Hebrews and the Day of Atonement that forms the focus of this essay.

Focusing, then, both on the background and the central theme of the book (its Christology), this study proposes that the priesthood and the Day of Atonement define the contours of the Christology of Hebrews (Ladd 1974:577-584). ${ }^{2}$ As such, we suggest that the Day of Atonement is one avenue by which access to the book's Christological focus may be gained. It is thus our hypothesis that the Day of Atonement functions as a hermeneutical key to the Christology of Hebrews and - since this is the book's central theme - to the book of Hebrews as a whole.

The important role played by Christology in Hebrews raises the question of the extent to which the interpretation of the book's Christological agenda is contingent upon a firm grasp of the different worldview(s) and/or cultic references that underlie the book. Because we believe this to indeed be the case, we will turn, before coming to Christology and the Day of Atonement itself, to the cosmologies and worldviews underlying Hebrews. After considering Middle-Platonism (including Philo of Alexandria) and the Essene communities as interpretative systems vital to the interpretation of Hebrews, we turn briefly to two remnants of Judaism that are, from a cultic point of view, of some significance in the book, namely the Sabbath and the idea of enthronement in ancient Israel. At this point we will turn to the Day of Atonement itself, looking at its Old Testament and early Judaic context, before we will come to our specific focus, namely that this festival functions as a hermeneutical key in Hebrews.

\section{Cosmologies and Worldviews underlying Hebrews}

A case can be made for the book of Hebrews being a prime example of contextual theology. The book draws on worldviews from a number of contemporary movements and traditions (Punt 1997:119). ${ }^{3}$ A detailed reconstruction of this background falls beyond the scope of the present study. We will focus only on those aspects of 
the worldview(s) reflected in Hebrews that shed light on the function of the Day of Atonement in developing the Christology of the book.

Much of the debate surrounding the worldview(s) behind Hebrews has centered on what is sometimes presented as an either/or choice between vertical (or MiddlePlatonic) and horizontal (or apocalyptic) dualism (Cf. for example Ladd 1974:572). It is to this issue that we now turn.

\subsection{Plato, Middle Platonism and Philo}

The book of Hebrews can be said to reflect, among others, a Middle-Platonic worldview. ${ }^{4}$ Probably originating in Alexandria, Middle-Platonism was prevalent in the Mediterranean world from approximately 50 B.C.E. to the end of the second century C.E. (Punt 1997:126). Platonism's characteristic distinction between the phenomenal (material, changing) realm and the noumenal (ideal, incorruptible) realm was in MiddlePlatonism merged with other philosophical patterns, e.g. Stoic ethics, Aristotelean logic, Neopythagorean metaphysics and religion (ibid.). ${ }^{5}$ The emphasis remained on the noumenal, primordial realm as opposed to the deriving material realm. ${ }^{6}$ Hebrews 12:18-29 is one of the texts in which Platonic dualism is most clearly reflected.

Drawing from Stoicism, Middle Platonism saw the material world as created by and infused with the Logos, which was understood to give origin to the human spirit (Schenck 2003:29). This provided humankind's link with the absolutely transcendent Supreme Mind (God), so that human access to the noumenal realm was gained through intellectual knowledge (Punt 1997:126). The Logos was also understood as residing in humans, enabling them to do good (De Jonge 1983:4-5). ${ }^{7}$

There are significant similarities between the Platonism underlying Hebrews, and that of Philo of Alexandria and the Book of Wisdom (De Villiers \& Du Toit 1990:8991; Johnson 1999:n.p.; Schenck 2003:29). ${ }^{8}$ Philo's worldview is more accurately called a hybrid of Platonic metaphysics and Semitic cosmology (Johnson 1999:n.p.). In his interpretation of the Pentateuch, Philo drew extensively from the Middle Platonic worldview, integrating it with his Semitic background in order to present Moses' teachings as Platonic and Judaism as a logical religion. A similar tendency is found in Hebrews (Du Toit 2002:27), although scholars are often divided on the extent to which these similarities derive from direct literary dependence. ${ }^{9}$ Furthermore, Philo saw the High Priest of the tabernacle as the representative of the Logos (De Jonge 1983:5).

There are differences between Philo and Hebrews. The Platonic and especially the Philonic idea of the ascent or rise of the soul does not occur as such. Instead, Hebrews' view is that Christ as the heavenly Son of God arrived in the world and returned to heaven by offering his body on earth (Stegemann \& Stegemann 2005:19; cf. for example Heb 9:28; 10:11-14). Although Hebrews makes extensive use of a Platonic world view, he combines it creatively with aspects rooted in Judaistic cultic experience (Horbury 1983:66). 


\subsection{Essene Communities}

The strong emphasis on the New Covenant (Heb 8-10) may reflect a background of Essene beliefs. The Essene community perceived themselves as living under the New Covenant, and celebrated annually the renewing of the covenant on Shavuot (Pentecost). If the readers of Hebrews shared Essene sympathies, they would therefore have felt at home with the emphasis on the end of days that is found at the outset of Hebrews (Fischer 1989:183). Hebrews was likely written in a tense period before the revolt against Rome, when the Messianic Jews were facing a difficult choice and test of loyalty either to their nation or their Messiah (ibid.). Qumran envisioned the Messiah as a purely human figure, whereas Hebrews envisions an outspoken heavenly figure (De Jonge 1983:3).

Yadin has argued that the unique heavenly position occupied by Melchizedek at Qumran explains his appearance in Hebrews to convey the author's conception of the uniqueness of Jesus (Yadin 1965:152ff). Strugnell published fragments of a work of cave four at Qumran which is more consistently concerned with the angels and the heavens than any other surviving work from Qumran and which must according to Strugnell represent the original theology of the sect (Strugnell 1960:318-345). Bruce has, however, denied a Qumranic destination to Hebrews (Bruce 1963:217-232). Little consideration is given to the striking linguistic and conceptual differences between Hebrews (written in an exceptional Greek and thus Hellenistic-Jewish in conception) and the scrolls from Qumran (written in Hebrew and Aramaic and thus Semitic in conception) (Lane 1991:n.p.). Qumran advocated the Levi tradition as opposed to Hebrews that drew from the non-Levite tradition of Melchizedek (De Jonge 1983:3). There is no watertight argument for the affirmation that Qumran provides the conceptual background for Hebrews (Lane 1991:n.p.), and the similarities of Qumran and Hebrews can be ascribed to the influence of Palestinian Judaism (Punt 1997:138).

\subsubsection{The Tabernacle}

Throughout Hebrews, the author refers to the tabernacle as the liturgical space for the Day of Atonement ritual and not the physical temple and cult as situated in Jerusalem (Johnson 1999:n.p.; cf. for example Heb 7:13; 8:5; 9:1-11; 9:24). The tabernacle, also referred to as the "tent of meeting", served as the central place of worship in the Israelite cult (Friedman 1992:292). This shrine housed the Ark of the Covenant and was frequently the location of revelation (Friedman 1992:292). The architecture of the tabernacle presents one of the classical problems in biblical scholarship (Friedman 1992:295). Although there are no specifics in relation to the construction of the tabernacle, it is possible to form a rough idea of its composition. The tent functioned in two parts, a holy inner tent, which was forbidden to everyone except the High Priest on the Day of Atonement, and an outer tent in which the daily religious rites and rituals took place (ibid.). 


\subsubsection{Melchizedek}

Melchizedek is only mentioned in two Old Testament passages, namely Genesis 14:1820 and Psalm 110:4 (Mason 2008:138). Although the priesthood was entrusted to the tribe of Levi, king Melchizedek ${ }^{10}$ is presented as a pre-Sinaitic priest of Jerusalem whose priesthood was approved by Abraham's tithe (Willi-Plein 2005:28). In Hebrews, Melchizedek is mentioned to furnish the book's Christology with an image of priesthood that stands in contrast to that of Aaron (Dunhill 1992:165). The author stresses the discontinuity between the priesthood of Melchizedek and Israel's later Levitical priesthood to whom the tithe was paid in actual practice. This differs from the continuity between the two priesthoods found in Philo (Mason 2008:160).

Melchizedek thus functions as a scriptural basis for a divinely authorised nonAaronic and even non-Jewish priesthood (Dunhill 1992:164). Melchizedek is represented as an ideal of priesthood and of priestly and kingly functions, which later arose in the ideology of the Hasmonean kings and that of their opponents expressed in the hope for the two-messiahs or single priest-king-messiah found in Qumran texts ${ }^{11}$ (Dunhill 1992:165). The Levitical priesthood is surpassed by Christ's priesthood (WilliPlein 2005:29). The Levite priests, previously privileged to dwell in God's house, has now been discharged of their former duties of "covering" or "atoning" for sin (Dunhill 1992:88). Melchizedek is a priest without genealogy since he is not a Levite, thus the reference to the non-Levitical Christ that proves to be the heavenly High Priest (WilliPlein 2005:28). Melchizedek poses no threat to Christ and is important to Hebrews as the bringer of non-order. Symbolically, therefore, he functions in the paradoxical role as Priest-Stranger as a double-Christ, both like and unlike (Dunhill 1992:165). Christ is portrayed in Hebrews as neither Melchizedek nor Michael, but as superior to both the angels and Melchizedek (McRay 1980:3; cf. e.g., Heb 1:4-14; 5:5-6).

\subsubsection{Judaic Apocalypticism}

Four features in Hebrews characterises it as apocalyptic literature: firstly, the esoteric treatment of the angels and Melchizedek as well as the liturgy of the tabernacle; secondly, it is literary in its identifying form; thirdly, it is symbolic in much of its language, identifying Christ as the sacrificial lamb, the veil of the tabernacle, the High Priest who passed through the heavens, and the great shepherd of the sheep; and, fourthly, although not pseudonymous, it is of course anonymous (McRay 1980:1). While echoes of apocalyptic thought resound from every quarter of Hebrews, the argument is not being made that the book is apocalyptic in the traditional understanding of that term (McRay 1980:2). Hebrews does not argue or explain the classical view, rather, it presupposes it and proceeds to set its picture of the high priestly work of Christ against this apocalyptic background (McRay 1980:4). The search for a perfect correspondence between one tradition and the particular form of Apocalypticism in Hebrews is futile, for the book reshapes the available symbols around the figure of the crucified and exalted Messiah, giving configuration to its content (Johnson 1990:n.p.). 


\subsection{Remnants of Judaism}

\subsubsection{Sabbath}

The original Sabbath as intended in Genesis was neither an enforced day of rest nor a prescribed ritual observance. The day appears to have had its origin as a day of rest in the wilderness tradition of the Pentateuch, where the Israelites were prohibited from gathering mannah on the seventh day (Exod 16:13-29) (Bloch 1978:1). The Pentateuch further describes special sacrifices that were offered on the Sabbath (Num 28:9), accompanied by the renewal of the Bread of the Presence (Lev 24:8). It can also be described as a day of special seriousness (Morris 1955:11). Eventually, the day came to be seen as holy, as a portion of the Israelites' time consecrated to Yahweh. This was modeled on the idea of God's rest after the act of creation, and served as a reminder of the relief granted by God when he delivered his people from slavery in Egypt (Westerholm \& Evans 2000:n.p.).

When the author of Hebrews urges his readers to enter "God's rest", the reference is to no particular holy day, but to the "eschatological fulfillment of God's will" (Du Toit 2002:84; Westerholm \& Evans 2000:n.p.). Based on his interpretation of Israel's history, there remains a sabbath rest ( $\sigma \alpha \beta \beta \alpha \tau \iota \sigma \mu o ́ s)$ for the people of God, which (although now only partially fulfilled [Brown 1971:410]), will become realised as God's will becomes eschatological reality (ibid.).

\subsubsection{Enthronement Festival}

The Old Testament notion of the cult as an audience before the great King's throne, where a person has the opportunity to make a request or to find favour, also appears in Hebrews (Willi-Plein 2005:28). If the temple or tabernacle is seen as a palace of the King to whose throne human requests were brought, then an introduction rendered by appointed priests, and especially the High Priest, was necessary. Homage and gifts is of great importance in this context (Willi-Plein 2005:28).

Hebrews 3:7-4:11 refers to Psalm 95 (Allen 2007:130), which together with Psalms 93-99, proclaims the kingship of Yahweh. Although an exact historical reconstruction of the usage of such Kingship Psalms in Israelite worship is fraught with difficulty, ${ }^{12}$ they were allegedly recited annually at Yahweh's ritual enthronement by Israel (Allen 2007:136). Provided that scholars are correct in their designated Sitz im Leben for the Enthronement Psalms, it seems possible that the idea of an enthronement feast or ritual might lie behind Hebrews' description of Christ's ascent to the right hand of his father. If this is the case, then the reference to Psalm 95 should be seen as deliberate.

\section{The Day of Atonement in the Old Testament and Early Judaism}

The Day of Atonement is one of the most important festivals of the Old Testament. Although this festival is not explicitly mentioned in the book of Hebrews, it is clearly 
alluded to. ${ }^{13}$ The theme of atonement is merely incidental at Passover, Shavuot and Rosh Hashanah, but it is the raison d'etre of the solemn day of the Day of Atonement festival (Bloch 1978:27). Philo linked the timing of the Day of Atonement to the ingathering of the harvest and the influx of material wealth which coincided with that season of the year, and asserted that the fast was designated to warn people against placing their trust in wealth, which may dissipate (Bloch 1978:29). According to Philo, the High Priest is the highest link to God and exercises his function of intercession especially on the Day of Atonement (De Jonge 1983:9).

In the ancient Mediterranean world, the offering of sacrifices was a natural means of communication with heaven, either as a means of sharing one's wealth with God (Bloch 1978:29), or as a way of appeasing the gods. The priesthood was perceived by the Jews and Greeks to give meaning and success to human life in two dimensions: firstly, the priesthood provided access to the deity where the Jews specifically focussed on the High Priest's role during the Day of Atonement; and secondly, the routine performance of the designated rituals by the priesthood guaranteed the security and good fortunes of the people (Songer 1985:345). ${ }^{14}$

A detailed account of the Day of Atonement is found in Leviticus 16 (Morris 1955:11). This highly significant day was regarded with utmost seriousness and carried the message that the state of separation from God, caused by sin, needed rectification (Morris 1955:12). Despite the sacrifices Israel performed on an ongoing basis, the Day of Atonement reminded Israel that all sins had not been fully atoned (Tenney 1980:413). The Day of Atonement attended to this problem by transferring the sins of the people onto a scapegoat (Morris 1955:12). Two goats were used in the ritual, the one intended for Yahweh, and the other for Azazel. ${ }^{15}$ The scapegoat, combined with the shedding of blood during the sacrifice, was to cleanse Israel completely of her sins (Tenney 1980:413).${ }^{16}$ Leviticus 17:11 establishes a connection between blood and the exchange of a life as atonement of sins, in the context of animal sacrifices as prescribed by the Torah, which does not tolerate human sacrifice (DeSilva 2000:276). In Hebrews, sacrifice does not hermeneutically imply the bloody offering on the altar, but refers rather to the bending of a person's will to the divine will (Hughes 1979:103). This agrees with the Hellenistic enlightenment concept of sacrifice, namely that true sacrifice demands neither the blood of animals nor a physical sanctuary (Thompson 1982:103).

Morris (1955:12-16) describes the events surrounding the Day of Atonement: According to Rabbinic literature the Day of Atonement had become the most important cultic day of the year by New Testament times. The High Priest ${ }^{17}$ stayed in the temple for seven days prior to this day, and on the third and seventh days was sprinkled with the ashes of a heifer, as a precaution to incidental impurity. This was also the only day in the year when the High Priest used the sacred Name of Yahweh. The culmination of the ritual responsibilities of the High Priest was found in his entrance into the Holy of Holies, since this was the only day in the year that this was allowed. It is interesting that the emphasis of this passage is on the access into the Holy of Holies, rather than on the atonement. The Mishnah emphasises that the Day of Atonement consists of an attitude 
of penitence and that in this lays the reconciliation between Yahweh and His people. The Rabbinic tractate Yoma stipulates that the lack of repentance, would undo the atoning act. In the same way repentance without the ritual was also of no avail. ${ }^{18}$

\section{The Day of Atonement as Hermeneutical Key in Hebrews}

The writer of Hebrews combines Judaic cultic remnants and Judaic cosmology with the Middle Platonic worldview in a creative way (cf. sections 2 and 3). This crosscosmological worldview pollination offers a unique key to the understanding of the Christology of Hebrews and thus the book of Hebrews itself.

The first reinterpretation pertains to the functioning of the tabernacle. The author of Hebrews views the historical tabernacle as a shadowy copy of the ideal heavenly tabernacle (Omanson 1985:363). This is emphasized in the use of the terms tupos for heaven and antitupos for the tabernacle (McRay 1980:4 cf. for example Heb 8:5; 9:24). The tabernacle space, as pictured in Leviticus, is significantly re-orientated. Instead of using the two-roomed structure of the tabernacle in a horizontal plane, the author of Hebrews applies it in a vertical plain between the phenomenal and the noumenal world (Schenck 2005:140-141; Gray 2005:n.p.; Du Toit 2002:138). It is in this religious focal space, noumenally reorientated, that the author of the book of Hebrews places the work of Jesus Christ as the High Priest par excellence (Cortez 2006:543).

The role of the High Priest during the Day of Atonement, the climax of the Judaic liturgical year, was to make a sacrifice for the people, achieving atonement through the blood of the sacrificial victim sprinkled in the Holy of Holies. When it comes to New Testament allusions to the Day of Atonement, it is important to note that animal sacrifices could never fully eradicate the effects of sin, because the sacrificial ritual was always performed and achieved in the phenomenal realm (Morris 1955:19). While the offering of sacrificial blood in the Holy of Holies lays down the principal of atonement, it stays a shadowy copy of the ideal atonement (cf. Omanson 1985:363; Morris 1955:19).

The author of Hebrews employs the Middle Platonic worldview to contrast the superiority of Christ's sacrifice to that of the Levitical system (De Villiers \& Du Toit 1990:99 cf. for example Heb 7:11-22). The cultic language in Hebrews is not a substitute for the true meaning of the death of Jesus, but refers to Christ as the real High Priest and of his death as real sacrifice (Stegemann \& Stegemann 2005:18). The intention is that through the self-sacrifice of the High Priest Jesus Christ, the heavenly cult transcends the earthly cult which is "a shadowy copy" of it (Stegemann \& Stegemann 2005:18). Thus the sacrifice offered by Christ resides in the noumenal world and therefore exceeds the material sacrifices and accomplishes complete atonement (Cortez 2006:545 cf. for example Heb 9:11-14; 10:19-21). According to Tenney (1980:409), Christ's sacrifice brought a new covenant: whereas the High Priest had to perform the sacrificial rituals for Israel every year, Christ entered into God's presence once and through his blood made lasting deliverance possible for all humankind. ${ }^{19}$ 
Cortez agrees with this when he states that the allusions to the Day of Atonement act as a metaphor for transition (Cortez 2006:543). He describes four movements between the phenomenal and noumenal world that serve as characteristics of the new covenant, namely the ministry of one high priest (in antithesis of the multiple priests of the old covenant), one sacrifice (in antithesis to the multiple sacrifices of the old covenant), access to the presence of God (in antithesis to ministry in the outer tent), and a cleansing of the conscience (in antithesis to the cleansing of the flesh provided by the old covenant) (ibid. cf. e.g., Heb 9:11-10:18).

\section{Conclusion}

The Christology found in Hebrews plays a central role in the understanding of the book. We propose that references to the Day of Atonement offer an interpreted religious and liturgical space for Christ to function as the superior High Priest. In this capacity, He is able to bring about a new covenant in which perfect atonement is achieved once and for all. It is from within this new covenant that previous observances are redefined and new meaning is given to reality. It is in this context that the Day of Atonement functions as a hermeneutical key in Hebrews. The use of the sacrifice as atonement encompasses the Christology of the book - Jesus becomes the ultimate sacrifice. Indeed, as Gäbel notes (2006:319):

Die kulttheologische Deutung der Erhöhung Christi ist bestimmt durch die Jom Kippur-Typlogie: Die Erhöhung Christi ist sein Eintritt ins himmlische Allerheiligste, seine hohepriesterliche Investitur und so auch die Darbringung seines Selbstropfers. Dieses bewirkt die Annullierung der Sünden. Deren Wirkung erstreckt sich auf alle Zeit von Grundlegung der Welt bis zur Parusie. So bleiben Gegenwart und Zukunft durch das zurückliegende Ereignis der Erhöhung Christi bestimmt. Auch das findet seinen Ausdruck im Rahmen der Jom Kippur-Typologie: Die Gegenwart entspricht der Zeit, während derer der Hohepriester am Jom Kippur nach vollzogenem Sühnakt im Heiligtum Fürbitte hält; die Parusie wird dem Hervortreten des Hohenpriesters aus dem Heiligtum entsprechen. Die Hohepriesterchristologie des Hebr erschließt durch die kulttheologische Deutung der Erhöhung deren unüberbietbare soteriologische Bedeutsamkeit.

\section{NOTES}

1 The Day of Atonement is not specifically mentioned in Hebrews, although traces of it can be found (e.g., Heb 5:1-3; 7:27; 8:11; 9:12).

2 Georg Gäbel, in his revised dissertation, similarly "locates the cultic theology of Hebrews against the background of its counterpart in early Judaism" (Mitchell 2008:106). Reading Hebrews as a pre-70 CE document, Gäbel argues three theses: 1) the coherent Christological design of Hebrews presents the exultation of Christ as the continuation of the (sic) his earthly life now lived in heaven; 2) the theology of the sanctuary in Hebrews draws upon the relationship between an archetype and its likeness in early Judaism and gives it its own twist, where the exaltation of Christ expresses the realization of holiness; and, 3) the situation of the recipients 
of Hebrews as strangers on earth is the exact opposite of their true membership in the heavenly sanctuary and their participation in the heavenly worship, which is demonstrated in their earthly fidelity" (Mitchell 2008:106-107; cf. Gäbel 2006:17).

3 This becomes visible in the way that Hebrews uses several Greek expressions such as $\dot{\alpha} \pi \alpha u ́ \gamma \alpha \sigma \mu \alpha$ "radiance" (1:3) and $\dot{\alpha} v \tau i ́ \tau v \pi \alpha$ "copy" (9:24), as well as through its employment of Judaic motifs such as the High Priesthood of Melchizedek $(5: 6 ; 7: 1-10,28)$ and allusions to cultic practices (9:1-10;13:10) (De Villiers \& Du Toit 1990:90).

4 Plato's metaphysics had become both a common consciousness and a theoretical worldview by the first century (Johnson 1999:n.p.). Johnson (1986:421-422 in Punt 1997:128-129) bases his typology of Hebrews as Middle-Platonic on the fact that the book shares the language, historical consciousness, as well as certain fundamental perceptions displayed in the writings of Philo.

5 It was precisely this fusion that made Middle-Platonism a fertile resource for theological reflection, since it moved beyond the earlier tendency of maintaining distance between philosophers and religion, to the point that religion came to be viewed as a "source of enlightenment" (Ferguson 1993:364 in Punt 1997:127). It is in this context that the apologetic works of Philo of Alexandria should be understood.

6 "The distinction is metaphysical (one realm of being is denser and more 'real' than the other), epistemological (the world of change allows only approximate perceptions - i.e., 'opinions' - whereas ideas can be truly 'known') and axiological (the noumenal world is "better" than the phenomenal)" (Johnson 1999:n.p.). Also, according to Eisele, "Grundlegend für das Wirklichkeitsverständnis, das der Hebräerbrief mit den untersuchten mittelplatonischen Autoren teilt, ist die ontologische Diastase zwischen der verstandesmäßigen Welt des wahren, unveränderlichen Seins und der wahrnehmbaren Welt des ununterbrochenen Werdens und Vergehens" (2003:426).

7 While the author of Hebrews does not explicitly identify Christ as the Logos, as for example in the prologue to the fourth gospel (John 1:1), the idea of God "speaking" to people is found throughout the book. The very first verse of the book links this idea to Christology: in the last days, this "speaking" ( $\dot{\lambda} \lambda \alpha \dot{\alpha} \eta \sigma \varepsilon v)$ has been by his Son (1:1-2).

8 Scholars have emphasised a shared conceptual world, especially as far as the eschatology of Hebrews is concerned (Isaacs 1992:57 in Punt 1997:129).

9 For Ellingworth, the similarities between Hebrews and Philo can be traced to a "common Jewish exegetical tradition; other similarities to hellenistic Jewish, or more specifically to Alexandrian tradition."He accounts for the differences between them by identifying the author of Hebrews as a "Jewish Christian," and Philo as a "philosophically minded diaspora Jew" (1993:47).

10 Contrary to Dunhill (1992:164), who states that Melchizedek is etymologically "whole king," and argues that he was already circumcised at birth, the name is a combination of קדצ רלע, and thus etymologically "king of righteousness."

11 In a fragmentary midrashic document from Qumran, Melchizedek is portrayed as a superior angel who has a special relation to the law of jubilee and a special function of caring for the people of God (McRay 1980:3).

12 It must be stated that there exists no clear evidence of an enthronement ritual in Israel.

13 Cf. for example Heb 5:1-3; 7:27; 8:11; 9:12).

14 The perception of priesthood in the first century entailed that to have a better priest was to have a fuller assurance of the favour of the divinity and a guarantee of the future quality of one's life 
as both of these realities were anchored inseparably to the power of one's supporting priesthood (Songer 1985:345).

15 Azazel was an attenuated demonic figure who lived in the wilderness. In Leviticus, however, this probably refers to a geographical place rather than an active supernatural figure (Wright 1992:73).

16 Sacrificial rituals did not necessitate animal slaughter, and wheat, oil and frankincense could still be viewed as a full "offering" (Eberhart 2005:45). The law on sin offering stipulates that in case of neediness, a grain offering can be substituted for the customary animal offering (Eberhart 2005:45).

17 The main task of the High Priest was to maintain communication with God. The climax of this function occurred with the High Priests entering the holy of holies and thus gaining access to the throne (Willi-Plein 2005:30).

18 "There is no process of magic or compulsion, nor do we see pagan ideas of appeasement. Atonement takes place only because God wills it and has ordained means whereby it may be accomplished" (Morris 1955:19).

19 It seems as if the idea of Christ as High Priest is not originally from the author. Expressions like

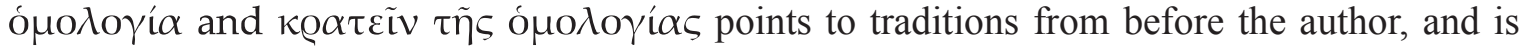
already part of the liturgies of the church at this stage (De Jonge 1983:7). Also, Gäbel formulates as follows on Christ's exaltation: "Durchs Todesleiden hindurch erlangte Christus in seiner Erhöhung die Qualität des Heilsmittlers: In seiner Erhöhung ist den vielen »Brüdern« gleiche Herrlichkeit verbürgt wie ihm selbst. So ist er durch Leiden »vollendet«. Mit »Vollendung« ist im Hebr die unüberbietbare, eschatologische Heilsfülle angesprochen, die im Weg Jesu Christi erschlossen und den Seinen zugeeignet ist. Aus der Erhöhung Christi geht die Gemeinde der »Söhne«, »Brüder«, »Geschwister« hervor, welche mit der himmlischen $\dot{\varepsilon} \kappa \kappa \lambda \eta \sigma i ́ \alpha$ verbunden ist. So erschließt die Erhöhung die Heilsbedeutung des irdischen Weges Christi. Dieser war der Weg des in der Versuchung Gehorsamen: Christus ist der wahre »Mensch«, in dessen Weg der Fall Adams aufgehoben und in dessen Herrschaft dem Menschengeschlecht die ihm von Gott bestimmte Herrlichkeit gegeben ist. Die Herrlichkeit des Erhöhten, die Heilsbedeutung der Erhöhung (und durch sie die des irdischen Weges Christi) bietet Hebr gegen die Anfechtung durch die vorfindlichirdische Schwäche des Menschen auf. So begründet er die fortdauernde Geltung des überkommenen Kerygmas von Erniedrigung und Erhöhung Christi” (2006:170).

\section{BIBLIOGRAPHY}

Allen, D. 2007. More than just numbers: Deuteronomic influences in Hebrews 3:7-4:11. TB 58/1:129149.

Bloch, A. B. 1978. The biblical and historical background of the Jewish holy days. KTAV, New York. Brown, C. 1978. NIDNTT Vol. 3. Oxford University Press, Cape Town.

Bruce, F. F. 1963.“To the Hebrews" or "to the Essenes”? NTS 9:217-232.

Cortez F. H. 2006. From the Holy to the most holy place: The Period of Hebrews 9:6-10 and the Day of Atonement as a metaphor of transition. JBL 125/3:527-547.

DeSilva, D. A. 2000. Perseverance in gratitude: A socio-rhetorical commentary on the Epistle "to the Hebrews.” Eerdmans, Grands Rapids. 
De Jonge, H. J. 1983. Traditie en exegese: De hogepriester-christologie en Melchizedek in Hebreeën. NTT 37/1:1-19.

De Villiers, J. L. and A. B. du Toit 1990. Teologie van Hebreërs. In Handleiding by die Nuwe Testament, Band 6: Die Johannesevangelie; Hebreërs tot Openbaring: Inleiding en teologie. Edited by A. B. du Toit, 89-112. NG Kerkboekhandel, Pretoria.

Du Toit, A. B. 2002. Hebreërs vir vandag: 'n Bybelstudie vir dieper delwers. Christelike Uitgewersmaatskappy, Vereeniging.

Dunhill, J. 1992. Covenant and sacrifice in the letter to the Hebrews. University Press, Cambridge.

Eberhart, C. A. 2005. Characteristics of sacrificial metaphors in Hebrews. Biblical Interpretation Series 75:37-64.

Eisele, W. 2003. Ein unerschütterliches reich: Die mittelplatonische umformung des parusiegedankens im Hebräerbrief. Beihefte zur Zeitschrift für die neutestamentliche Wissenschaft und die Kunde der alteren Kirche 116. De Gruyter, Berlin.

Ellingworth, P. 1993. The Epistle to the Hebrews: A commentary on the Greek text. NIGTC. Eerdmans, Grand Rapids.

Ferguson, E. 1993. Backgrounds of early Christianity. 2nd ed. Eerdmans, Grand Rapids.

Fischer, J. 1989. Covenant, fulfillment and Judaism in Hebrews. Evangelical Review of Theology 13/2:175-187.

Friedman, R. E. 1992. s v “Tabernacle.” In $A B D$, vol. 6. Edited by D. N. Freedman, 6 vols, 292-300. Doubleday, New York.

Gäbel, G. 2006. Die kulttheologie des Hebräerbriefes: Eine exegetisch-religionsgeschichtliche studie. WUNT 2/212. Mohr Siebeck, Tübingen.

Gray, P. 2005. Review of Eisele, W., Ein unerschütterliches Reich. Review of Biblical Literature. February 2005. Online: http://www.bookreviews.org/pdf/4687_4797.pdf-accessed 6 June 2011.

Horbury, W. 1983. The Aaronic priesthood in the Epistle to the Hebrews. JSNT 19:43-71.

Hughes, G. 1979. Hebrews and hermeneutics: The Epistle to the Hebrews as a New Testament example of biblical interpretation. Cambridge University Press, Cambridge.

Isaacs, M. E. 1992. Sacred space: An approach to the theology of the Epistle to the Hebrews. JSNT Supplement Series 73. JSOT, Sheffield.

Johnson, L. T. 1986. The writings of the New Testament: An interpretation. Fortress, Philadelphia.

Johnson, L. T. 1999. The writings of the New Testament: An interpretation. Electronic ed. Fortress, Minneapolis.

Ladd, G. E. 1974. A theology of the New Testament. Eerdmans, Grand Rapids.

Lane, W. L. 1991. Hebrews 1-8. WBC 47A. Electronic ed. Word, Dallas.

Mason, E. F. 2008. You are a priest forever: Second Temple Jewish Messianism and the priestly christology of the Epistle to the Hebrews. Brill, Leiden.

McRay, J. 1980. Atonement and apocalyptic in the Book of Hebrews. ResQ 23/1:1-9.

Mitchell, A. C. 2008. Review of Gäbel, G., Die Kulttheologie des Hebräerbriefes. RelSRev 34/2:106107.

Morris, L. 1955. The Day of Atonement and the work of Christ. RTR 14/1:9-19.

Omanson, R. L. 1985. A superior covenant: Hebrews 8:1-10:18. Review \& Expositor 82/3:361-373. 
Punt, J. 1997. Hebrews, through-patterns and context: Aspects of the background of Hebrews. Neot 31/1:119-158.

Schenck, K. L. 2003. Understanding the book of Hebrews: The story behind the sermon. Westminster John Knox, Louisville.

Schenck, K. L. 2005. Review of Eisele, W., Ein unerschütterliches Reich. CBQ 67:140-141.

Son, K. 2005. Zion symbolism in Hebrews: Hebrews 12:18-24 as a hermeneutical key to the epistle. Paternoster, Milton.

Songer, H. S. 1985. A superior priesthood: Hebrews 4:14-7:27. Review \& Expositor 82/3:345-359.

Stegemann, E. W. And W. S. Stegemann. 2005. Does the cultic language in Hebrews represent sacrificial metaphors? Reflections on some basic problems. Biblical Interpretation Series 75:1323.

Strugnell, J. S. 1960. The Angellic Liturgy at Qumram: 4Q Serek Sirot Olat Hassabbat. VTSup 7:318 345.

Tenney, M. C. (ed.) 1980. The Zondervan pictoral encyclopedia of the Bible Vol 1. Zondervan, Grand Rapids.

Thompson, J. W. 1982. The beginnings of the Christian philosophy: The Epistle to the Hebrews. Catholic Biblical Quarterly Monograph Series 13. The Catholic Biblical Association of America, Washington.

Westerholm S. and C. A. Evans. 2000. s v "Sabbath.” In DNTB. Edited by C. A.Evans and S. E. Porter. Electronic ed. InterVarsity, Downer's Grove.

Willi-Plein, I. 2005. Some remarks on Hebrews from the viewpoint of Old Testament exegesis. Biblical Interpretation Series 75:25-35.

Wright, D. P. 1992. s v. Day of Atonement. In ABD, vol. 2. Edited by D N. Freedman, 6 vols, 72-76. Doubleday, New York.

Yadin, Y. 1965. A note on Melchizedek and Zumran. IEJ 15:152-154. 